\title{
MICOTOXINAS NA ALIMENTAÇÃO DO GADE LEITEIRO DA REGIÃO METROPOLITANA DE CURITIBA: UM (DES)CONHECIMENTO QUE FAZ DIFERENÇA
}

\author{
Lia Suzana Guimarães Coimbra \\ Orientador: Prof. Dr. Valdo José Cavallet
}

\begin{abstract}
RESUMO
No presente trabalho obteve-se informações referentes ao conhecimento dos produtores de leite da Bacia Leiteira da Região Metropolitana de Curitiba, em relação as micotoxinas presentes na alimentação do gado leiteiro, bem como, sobre a orientação fornecida ao criadores de bovino leiteiro da região e qual a participação de instituições públicas no controle destas contaminações, a fim de minimizar os danos para os animais e a saúde humana, evitando prejuízos de ordem social e econômica. A metodologia escolhida fundamentou-se em abordagens qualitativas usando-se entrevista como processo de coleta de dados. As entrevistas foram realizadas com doze produtores de grandes, médias e pequenas propriedades. Técnicos de instituições públicas e privadas foram entrevistados sobre a fiscalização, controle e legislação específica do assunto. Observou-se durante a análise dos resultados que os produtores de leite não conhecem as micotoxinas e os danos causados por elas, porém, $100 \%$ deles descartaram rações e silagens mofadas. Verificou-se também que não há fiscalização e controle eficiente pelos órgãos governamentais. Cabe, portanto, aos órgãos competentes, aos profissionais envolvidos na área, bem como as Universidade, levar conhecimento sobre o assunto aos produtores de leite para que possam ser tomadas as medidas profiláticas viáveis.
\end{abstract}

\begin{abstract}
The present work aimed at obtaining information about the level of knowledge that milk producers in the greater Curitiba milk belt had about the presence of mycotoxins in feedstuff given to dairy cows. The work also aimed at verifying the orientation given to dairy farmers, and the role governmental institutions played in the control of milk contamination, with its known impact on human and animal health as well as on social and economic grounds. Methodological strategy has been based on "quality appraisal" using interviews as the process of data collection. Interviews have been conducted with twelve milk producers from either small, medium or large farms. Technicians from both private and Government Institutions were also questioned about the specific legislation on the issue. When analysing end results. one comes to the conclusion that dairy farmers are unaware of the existence of mycotoxins and their consequences. It has also been observed that there is no efficient inspection and / or control from government agencies. It is, therefore, incumbent on government officials, area-related professionals and the universities the task to take this issue and discuss it with the milk producers. making sure adequate prophylaxis can be applied.
\end{abstract}

Key-words: Milk quality. contaminated silage, aflatoxin9l, fungi. 